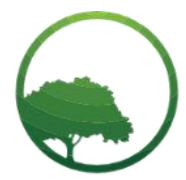

Business \& Social Science IJRBS

\section{Research in Business \& Social Science}

IJRBS VOL 10 NO 7 ISSN: 2147-4478

Available online at www.ssbfnet.com

Journal homepage: https://www.ssbfnet.com/ojs/index.php/ijrbs

\title{
Employees' self-efficacy and work performance of employees as mediated by work environment
}

\author{
Mary Joy Encarnacion ${ }^{(d)}$ \\ (a) Professor, School of Business and Administration, Divine Word College of Laoag, Ilocos Norte, Philippines \\ (b) Dean, School of Arts, Sciences and Education, Divine Word College of Laoag, Ilocos Norte, Philippines \\ ${ }^{(c)}$ Professor, School of Arts, Sciences and Education, Divine Word College of Laoag, Ilocos Norte, Philippines \\ (d) President, School of Religious Education, Saint Benedict College of Northern Luzon, Ilocos Sur, Philippines \\ ${ }^{(e)}$ Dean, School of Business Administration, Divine Word College of Vigan, Ilocos Sur, Philippines
}

D Damianus Abun ${ }^{(a) *(D)}$ Marlene T. Nicolas ${ }^{(b)}$ (D) Estrella P. Apollo ${ }^{(c))}$ (D) Theogenia Magallanes ${ }^{(d)}$

\begin{tabular}{l} 
A R T I C L E I N F O \\
\hline Article history: \\
Received 23 September2021 \\
Received in rev. form 24 Oct. 2021 \\
Accepted 29 October 2021 \\
Keywords: \\
Self-efficacy, work performance, \\
work environment, counterproductive \\
behaviors. \\
JEL Classification: \\
O15
\end{tabular}

\begin{abstract}
A B S T R A C T
The study aimed to determine the correlation between self-efficacy and work performance as mediated by the work environment. To support the theory of study, literature was reviewed. The study used the descriptive correlational research design and to gather the data, questionnaires were used. The population of the study was all the faculty and employees of the Divine Word Colleges in the Ilocos Region, Philippines. The study found that their self-efficacy is high and it affects the work performance specifically task and contextual work performance but no correlation with the counterproductive behavior. The study found that work environment affects self-efficacy and work performance along with the three dimensions such as task performance, contextual performance, and counterproductive work behavior. Therefore, the hypotheses of the study are accepted.
\end{abstract}

(C) 2021 by the authors. Licensee SSBFNET, Istanbul, Turkey. This article is an open access article distributed under the terms and conditions of the Creative Commons Attribution (CC BY) license (http://creativecommons.org/licenses/by/4.0/).

\section{Introduction}

Human resources' concern is always focusing on organizational performance. Organizational performance cannot be achieved without individual work performance. Managing organizational performance means managing individual work performance. Managing individual work performance has no single solution because performance can be affected by many factors. Factors that may affect performance are skills, knowledge, satisfaction, motivation, work environment, working relationship, etc. One of the factors that has not been given much attention by the management in the education setting is to consider self-efficacy in the performance management of its employees.

Human resources have been focusing on improving work performance which is the key to improve the quality of education, and thus, the office is tasked to analyze different factors that affect the employees' performance. The office has been researching many aspects that affect organizational performance such as employee treatment and performance (Abun, et.al, 2020), corporate transparency and engagement (Abun, et. al,2020), workplace relationship, and job satisfaction (Abun, et.al, 2019), and many more other researches. However, none has been done concerning self-efficacy and work performance. Self-efficacy is one of the important elements that cause work performance. In the business setting, some studies have been conducted along with the effect of self-efficacy on the work performance of employees such as Cetin and Askun (2018). Their study proved that self-efficacy has a significant correlation with job performance and productivity. Similar output was also presented by Machmud (2018, Paramita, et.al, 2020). Their study found that self-efficacy influences job satisfaction, work performance, and work engagement. The results of recent studies are consistent

* Corresponding author. ORCID ID: 0000-0002-9693-1541

(C) 2021 by the authors. Hosting by SSBFNET. Peer review under responsibility of Center for Strategic Studies in Business and Finance. https://doi.org/10.20525/ijrbs.v10i7.1470 
with the earlier studies on the effect of self-efficacy toward motivation and work performance such as the study of Randhawa (2004), Cherian and Jacob (2013), Tojjari, et.al (2013). The existing studies on self-efficacy and work performance were conducted in the business setting. There have been no studies yet concerning self-efficacy and work performance as mediated by the work environment in the education setting.

Based on the above studies, thus, the management needs to study the extent of self-efficacy of the faculty and employees and its effect on their work performance. It is also important to see how the work environment mediates the effect of self-efficacy on work performance. Faculty and employees' development program should be oriented toward enhancing self-efficacy which may lead to enhancing their performance and at the same time improve work environment which will help self-efficacy to flourish that consequently affect the performance. This area has not been touched by the researchers and therefore, this study is trying to close the gap. This study assumes that self-efficacy affects work performance as long as faculty and employees are experiencing a conducive working environment.

The objective of the study is not to problematize the self-efficacy theory because it is the domain of psychology but to use the theory to provide necessary information for the Human Resource Development office to design training and development programs to improve the work performance through improving employees' self-efficacy. Non- performing organizations cannot be blamed solely on salaries and benefits but other non-financial aspects need to be considered in enhancing work performance. The study is divided into several parts. The first part is the introduction which explains the rationale or the background of the study. The second part is the literature review. It will investigate the existing literature and studies that discuss self-efficacy and its effect on work performance which will establish the theoretical foundation of the study. The third part is the research methodology that explains the research design, population, locale of the study, research procedures, research instruments, and statistical instruments. The fourth part is the presentation of data and analysis. This part presents the data that was gathered through research questionnaires and tabulated using statistical software as the basis for interpretation and analysis. The fifth part is the result and discussion. This part discusses the further result of the study and the implication and its contribution to the theory of self-efficacy and work performance.

\section{The Literature Review}

This part investigates the existing theories of the study based on the literature and studies conducted by other researchers in the past. Therefore, the presentation of the theories is structured thematically. There are three main theories to be presented namely selfefficacy theory, individual work performance theory, the effect of self-efficacy and work performance, and work environment.

\section{Theory and Concept of Self-Efficacy}

Before going into the details, we need to define the difference between theory and concept. It is recognized that often time, people used the terms interchangeably because people often use theory to mean the concept or concept to mean theory. However, the two terms have different meanings. For the sake of our discussion, we use the terms theory. We use theory because it needs to be proven or tested when it comes to the correlation between self-efficacy and work performance. Koshal (2014) a linguistic expert explains the difference between theory and concept. According to him, a concept is a mental representation made from the physical material of the brain that enables human beings to draw inferences about things that they experience and encounter every day. While the theory is a collection of ideas, facts, phenomena that can be used to explain a certain topic. The difference between the two terms is apparent. The concept is an abstract notion but a theory is an explanation of a particular subject matter and these explanations are originated from the facts. Given the confusing nature of the two terms, we are going to use the term theory in this particular topic.

The theory of self-efficacy is begun by Bandura (1977) in his investigation on social learning theory which was later (1986) renamed to social cognitive theory. One of Bandura's concepts in his major theory, the social cognitive theory is self-efficacy (Zulkosky, 2009). Bandura (1977) defined self-efficacy as "people's beliefs in their capabilities to exercise control over their functioning and over events that affect their lives". Or, it is a" belief in one's capabilities to mobilize the motivation, cognitive resources, and course of action needed to meet given situational demands" (Wood \& Bandura, 1989). According to Bandura, self-efficacy affects motivation, well-being, and personal accomplishment. His study concluded that self-efficacy makes a difference among people on how they think, behave and motivate themselves to perform a certain activity. He found that low self-efficacy leads to stress, depression, anxiety, and helplessness. Such low self-efficacy affects their accomplishment. It also affects the way how people think and this is evident in the quality of decision making and accomplishment including academic achievement. It also affects how people behave particularly in the way how they choose and perform a certain activity. It influences the level of motivation. His study pointed out that people with a very high level of self-efficacy would not withdraw from the difficult task but they see it as a challenge (Bandura, 1989, 1995). According to this theory, self-efficacy affects how people set goals their goals to be accomplished. Those who have high self-efficacy tend to set higher goals compared to those who have low self-efficacy (Bandura, 1989). They tend to bounce back from failure and instead of giving up, they try to find ways to survive (Bandura, 1977b). This is also the case with the children. Children who have high self-efficacy produce better results compared to those who have low self-efficacy and they like solving difficult problems because they see problems positively (Crain, 2000). However, Zulkosky (2009) pointed out that given a person has too high self-efficacy but without proper training can lead to disaster. Take an example a person who overestimates his/her capability to run a marathon but gets injured because of lack of proper training. But for Bandura (1997) it is better to overestimate rather than underestimate to succeed. Results from organizational researches found a consistent finding that self-efficacy correlates 
to work-related outcomes, job attitudes (Saks, 1995), training proficiency (Martocchio \& Judge, 1997), and job performance (Stajkovic \& Luthans, 1998). According to Bandura (1977), self-efficacy is the product of experience. Bandura (1977) as cited by Lopes-Garrido (2020) identified four kinds of experiences that help a person to develop self-efficacy namely performance outcome, vicarious experiences, social persuasion, and emotional and physiological state. Performance outcome refers to positive past performance outcome experience. This is also called mastery experience because the present self-efficacy belief is built on the past successful experience. A Person has the self-confidence to take on a new job or new challenge because he/she has done it successfully in the past. Thus, on one hand, successful experience develops self-efficacy and motivates the person to take on the new assignments. On the other hand, failure undermines self -efficacy which leads a person to doubt his/her capability to take new challenges. While vicarious experiences are related to experience as a result of observing other people's experience on completing a task successfully. $\mathrm{He} / \mathrm{she}$ has seen someone who was accomplishing the task and based on his/her observation, he/she believes that he/she can also perform the same task successfully. The idea here is: "if he/she can do it, I can do it too". In other words, positive and negative vicarious experiences affect the self-confidence of someone to perform a new task. Another experience that can help self-efficacy to develop is social persuasion. This is about the experience as a result of receiving feedback from peers or superiors after completing a task. Encouragement or discouragement coming from other people may develop or undermine the self-confidence of a person to perform (Redmond, 2010). Along with such a concept, recognition of a work well done is important to develop self-efficacy. Lastly is an emotional and physiological state. This experience is a result of physiological and emotional reactions after performing a certain task. Bandura (1977) as cited by Lopes-Garrido (2020) pointed out that "people experience sensations from their body and how they perceive this emotional arousal influences their belief of efficacy".

Besides experiences as a factor influencing self-efficacy, the organizational research on self-efficacy pointed out the context or work environment as one of the factors that affect self-efficacy (Conger and Kanungo (1988). Though experience and context are referring to the same thing which experience, however, context is focusing on the working environment that promotes and demotes selfefficacy. Management and organizational theorists argued that the work environment or context where people are working can influence self-efficacy (Block,1987, Conger, 1986). This is also pointed out by Nordlof, et.al (2019) that self-efficacy is contextdependency which means that the social environment may limit or boost self-efficacy. An earlier study that supports this claim is the study of Raudenbush, et.al (1992). They studied the contextual effect on the self-perceived efficacy of high school teachers. Their study found that teachers who exercise control over key working conditions and work in highly collaborative environments have elevated self-efficacy. In a similar vein, Conger and Kanungo (1988) also pointed out context as one of the factors that affect selfefficacy and they identified several contexts that may affect self-efficacy and they are organizational factors, supervisory style, reward system, and job design. According to the very bureaucratic organizations, applying the authoritarian style of leadership, and a lack of reward system may affect the self-efficacy of employees.

\section{Individual Work Performance}

There is no other way to achieve competitiveness and organizational performance except through individual work performance. This has been the concern of every manager and human resource manager in particular. Finding ways and means to improve organizational performance and individual performance has no single solution. Problems are interconnected and thus focusing on one solution is simply wrong. Performance is simply the effect of many other factors such as job satisfaction, engagement, and commitment, working relationship, treatment, knowledge, skills, and self-efficacy. Given those factors are in place, then it is expected that employees can perform better. Thus, it is important to always evaluate the work performance of employees if they are doing their job as expected and leading toward the stated objectives. ork or job performance has been defined as "the act of doing a job and it is a means to reach the goal within a job or organization" (Campbell, 1990). This definition emphasizes work performance as a means to an end which is the goal of the job and the goal of the organization. This definition emphasizes performance as the means to an end and not the result. To facilitate the behavior or the means, every employee is given a job description or specific task behavior to be followed to achieve the objective of the job and the organization. Therefore, any behaviors or acts that are not in line with the attainment of the goal may be considered counterproductive behavior. Based on the definition of Campbell (1990), it is very clear that performance is not measured based on the outcomes but is the behavior to be measured. Therefore, the focus of individual performance measurement is on the behavior and not the outcome of the behavior (Koopmans, et.al, 2012). If the definition of Campbell (1990) focuses on the behavior of the employees as a basis for measuring work performance, however, Motowidlo (2003) focusing on the outcome of behavior. Motowidlo (2003) as cited by Martocchio (2015) defines job performance/work performance as "a total expected value to the organization of the discrete behavior episodes that an individual carries out over specified period". The important elements of this definition are a total expected value to the organization and discrete behavior. Thus, measuring work performance focuses on the outcome and the behavior. Total expected value contribution to the organization explains the overall added value contributed by the employees to increase the value of the organization or the success of the organization and making the organization better, more profitable, and a nicer place to work (Heatfield, 2021). Other definitions that focus on measuring performance based on the outcome are Nassazi (2013), Arinanye (2015). They measure task performance on the results, productivity, success, quality, efficiency, effectiveness, and work attendance. The confusing elements of work performance to be measured explain the complex nature of work performance. Such confusions cause disagreement among the researchers about what dimensions to measure in the task performance. It was either focusing on the outcome or output as a measure of individual work performance (Koopmans, 2012) or focusing on task performance which measures task proficiency that signifies employees' capability to perform their task (Campbell, 1990). According to Koopmans, et.al (2012) that the reason for conflicting measures is the definition of what constitutes an individual work 
performance is. Therefore, a clear definition and a theoretical framework about work performance must be established as a basis for the investigation. It has been recognized that work performance is not a single construct but it is a multidimensional construct (Campbell, 1990; Austin and Villanova, 1992, Short \& Palmer, 2003). For our investigation, the current researcher adopts the definition of Campbell (1990) about work performance as "the act of doing a job and it is a means to reach the goal within a job or organization". The focus of the investigation is measuring the discrete behavior of the employees in carrying out their duties and responsibilities. There have been many researchers who have conducted studies on measuring work performance focusing on the outcome, but measuring performance based on the outcome has been criticized because it does not reflect the different dimensions of work behaviors that constitute individual work performance (Campbell, 1990, Griffin, et.al, 1993, Koopmans, 2012, Abun, et.al, 2021). It is based on the definition of Campbell (1990), Koopmans, et.al (2011) opined that measuring individual work performance should focus on the behaviors that are under the employees' control and not the outcome because the outcome may not be within the control of employees. Motowidlo and Kell (2012) argued that the domain of performance is employees' behavior that contributes to the outcome. This was already pointed out earlier by Sonnentag and Frese (2002) as cited by Ching, et.al (2020) that only behaviors that are relevant for the organizational goals constitute performance. Thus, Koopmans, et.al (2012) developed individual work performance questionnaires which measure individual work performance (IWP) that is focusing on behavior, and finally, individual work performance has three dimensions such as task performance, contextual performance, and counterproductive work behavior.

Task performance is related to the capability of the person to carry out the job given to him/her. Borman and Motowidlo (2009) considered task performance as "the effectiveness of an employee to carry out his/her duties and responsibilities required by the job that contribute to the organization's technical core either directly by implementing a part of its technological process, or indirectly by providing it with needed materials or services". This concept refers to task performance as having the right technical knowledge and technical skills to perform the job which makes the individual effective and contribute to the organization's goals. Possessing the required technical knowledge and skills is a prerequisite to executing the task effectively. Similar to this definition is the definition of Robins and Judge (2013, p. 26) who define task performance as "the combination of effectiveness and efficiency at doing your core task". Thus, in line with such definitions, Campbell (1990) also defined task performance as "proficiency with which individuals perform the core substantive or technical tasks central to his or her job". The emphasis of this definition is technical proficiency that supports the employee to perform his/her duties and responsibilities. Thus, along this line, Koopmans (2011) considers task performance as a core responsibility of an employee or "role-prescribed behavior". Therefore, Rotundo and Sackett, (2002) identified different behaviors that describe task performance such as work quantity and quality, job skills, and job knowledge. If task performance is measured in terms of proficiency and competency, contextual performance is measured in terms of the positive behaviors that support the environment where employees can perform their duties and responsibilities. Borman and Motowidlo (1993) as cited by Koopmans, et.al (2012) define contextual performance as "behaviors that support the organizational, social, and psychological environment in which the technical core must function". These behaviors are not originated from employees' job descriptions but are extra-role behaviors that create a conducive working environment. In line with such concept, Podsakoff et al., (2000) as cited by Kalia and Bhardwaj (2019) opined that contextual performance refers to discretionary behavior of employees that promote a good working environment for the organization or "behaviors that directly promote the effective functioning of an organization without necessarily directly influencing an employee's productivity". Borman and Motowidlo (1993), Motowidlo and Van Scotter, (1994) had identified behaviors that are considered as a contextual behavior or contextual performance such as volunteering, helping, coming early to the office, going home late after everything is done and other kinds of behaviors that make the organizational environment conducive. Those kinds of behaviors are often called organizational citizenship behavior (Koopmans, et.al 2012) because they are discretionary in nature or non-required behavior by members of the organization that employs them (Organ, 2015). Research suggests that these kinds of behaviors are associated with a certain personality and OCB often predicts organizational effectiveness (Organ, 2015). The third dimension of individual work performance is counterproductive behavior. Counterproductive behaviors are also discretionary behaviors but they are counter to the organization's legitimate interest (Sackett \& DeVore, 2001). These behaviors are the opposite of organizational citizenship behaviors (Sypniewska, 2020). Sackett and DeVore (2002) defined counterproductive behavior as "any intentional behavior on the part of an organization member viewed by the organization as contrary to its legitimate interests". Sackett and DeVore (2002) had identified several behaviors that are considered counterproductive such as theft, destruction of property, misuse of information, misuse of time and resources, unsafe behavior, poor attendance, poor quality work, alcohol use, drug use, inappropriate verbal actions, inappropriate physical actions toward coworkers. Studies have been conducted related to the effect of counterproductive behavior and other organizational dimensions. Those studies found the correlation between counterproductive behavior affects satisfaction ((Mount, Ilies \& Johnson, 2006), organizational justice (Fox, Spector \& Miles, 2001), the quality and quality of work, and the quality of decision making (Macovei, 2016).

\section{Work Environment}

Managing productivity has no simple solution because it takes a comprehensive review of the interrelationship of different aspects of the organization and how it correlates and affects among units. Though there were no studies in the early 1900s efforts to improve employees' productivity were started by Taylor (Wladen, 2004). However, Taylor was focusing on the effect of incentives such as salary, production techniques, and work environment toward productivity. Concerning the work environment, it was referring to the physical work environment. The effort led to improve the physical working condition (Walden, 2004). Factors such as social process, well-being, and satisfaction were neglected. In the process of industrial growth, the concern to study different factors of work environment that affect productivity had begun. This leads us to the idea that there is no single solution to answer a certain problem 
within an organization. Therefore, solving a problem needs a deeper analysis of the causes of the problems and identify the main causes of the problems and address them. One of the problems that have not been given much attention by the management is the working environment. Studies have been conducted related to the effect of the working environment on productivity. For example, Awan and Tahir (2015), Duru and Shimawua (2017) examined the influence of the work environment on the level of productivity among employees in Pakistan, Nigeria, and their study showed that the working environment correlates to the level of productivity of employees. In a similar vein Al-Omari and Okasheh (2017), Pandey (2017) investigated the effect of work environment on job performance of employees in Jordan and their study also forwarded the similar finding that works environment influence job performance and productivity of employees. The concept of work environment has broadened and is not limited to the physical work environment. Merriam-Webster defines environment as "the circumstances, objects, or conditions by which one is surrounded" or "the aggregate of social and cultural conditions that influence the life of an individual or community". The definition refers to the environment not only to the physical environment but any conditions which include the social and cultural environment that affect a person. While Cambridge Dictionary defines environment as "the conditions that you live or work in and the way that they influence how you feel or how effectively you can work". The definition refers to the environment as surroundings or anything around us that affect our feeling and our behavior (Awan \& Tahir, 2015). These two definitions are enough basis for us to define environment as physical, psychological, social, and cultural conditions that affect our feeling, our thinking, and our behavior. Therefore working environment means anything that surrounds employees and affects their work performance (Al-Omari \& Okasheh, 2017). This definition does not limit the work environment as to the internal work environment but it also includes an external environment that may affect employees (Nitisemito, 1992). Operman (2002) as cited by Oludeyi (2015) defined work environment as a composition of three major elements such as technical environment, human environment, and organizational environment. The technical environment includes tools, equipment, technological infrastructure, and other physical or technical elements of the workplace. The human environment includes peers, others with whom employees relate, team and workgroups, interactional issues, leadership, and management. These elements explain the work environment as an interrelationship of different actors that affect the work behavior of employees. The organizational environment includes systems, procedures, practices, values, and philosophies which operate under the control of management. Concerning the human and organizational environment, Mansoor and Hassan (2016) identified several elements of the work environment that may affect work engagement such as communication, teamwork and collaboration, job role, company management, learning, and development. In addition to these elements, Othman, et.al (2019) three elements of the work environment that can affect work engagement such as leadership, compensation, and organizational culture. Briner (2000) as cited by Abun, et.al (2021) argued that the work environment is a broad concept that includes the physical and psychological setting of the workplace and therefore the concern of the work environment is not just about the physical setup of the workplace but it includes relationships and emotions among employees.

After reviewing different concepts of environment, one may come to a point of confusion on what elements to investigate because it is a broad concept that includes internal and external aspects such as physical, psychological, social, and cultural elements that affect the workplace and the employees. Investigating all elements of the work environment may not be possible to be done in one research. Therefore, the current research will investigate the internal work environment in terms of the human and organizational environment. The human environment refers to working relationships among employees and management and the organizational environment refers to the bureaucratic organizational environment. Employer-employee relationship refers to the harmonious working relationship between employees and employers in which the employees are allowed to participate in decision making. It may also indicate conflict and co-operation between employees and employers (Marchington and Wilkinson, 2005). Schreiner (2018) pointed out that managing the employer-employee relationship is vital to organizational success. While employee and employee relationships refer to the harmonious working relationship between employees. Employees must feel comfortable dealing with each other without hesitation. Such an environment is important for the employees to perform their functions happily and increase their confidence and morale (MSG, n.d). An organizational environment that this paper is investigating is the bureaucratic environment. A bureaucratic environment refers to an organization that is marked by rules, laws, procedures, and centralization of decision making. The purpose of these rules, regulations, and procedures is to control and direct all activities toward the desired end (Abun, 2021).

\section{Conceptual Framework}

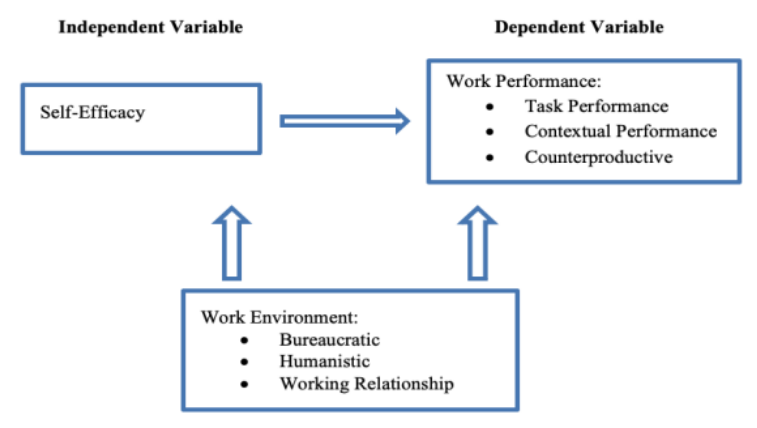

Figure 1: The framework reflects the correlation between self-efficacy and work performance as mediated by the work environment; Source: Schwarzer, R., \& Jerusalem, M. (1995), Abun, et.al (2021) and Koopmans, et.al (2012). 


\section{Statement of the Problems}

The study aims to determine the effect of self-efficacy of employees toward their work performance as mediated by the work environment. It seeks to answer the following questions:

i. What is the self-efficacy of the employees of Divine Word Colleges in the Ilocos Region?

ii. What is the individual work performance of employees of Divine Word Colleges in the Ilocos Region in terms of

a. Task performance

b. Contextual performance

c. Counterproductive work behavior

iii. What is the work environment of the Divine Word Colleges in the Ilocos Region in terms of

a. Bureaucratic environment

b. Humanistic environment

c. Working relationship

iv. Is there a relationship between self-efficacy and individual work performance?

v. Is there a relationship between work environment and self-efficacy?

vi. Is there a relationship between work environment and individual work performance?

\section{Assumption of the study}

The study assumes that self-efficacy influences the individual work performance of employees which is mediated by the work environment. It also assumes that the instruments are valid and reliable and the answers to those questionnaires are objective.

\section{Hypothesis}

Bandura (2001) has pointed out that a strong sense of self-efficacy improves achievement and personal welfare and helps people to perform difficult tasks. Based on such theory, the current study hypothesizes that self-efficacy affects the individual work performance of employees, and the work environment affects self-efficacy and work performance.

\section{The Scope and Delimitation of the Study}

The scope of the study is within the Divine Word Colleges in the Ilocos region and covers all employees of the colleges. It limits its investigation on the effect of self-efficacy toward work performance which includes task, contextual performance, and counterproductive work behavior as mediated by the work environment such as bureaucratic, humanistic, and working relationship.

\section{Research and Methodology}

As scientific research, the current research is following a specific method of investigation or research methodology. Wilkinson, (2000), Leedy, (1974) opined that research methodology is an established process for conducting the inquiry. It applies certain methods to determine, select, and analyze the data related to the concerned topic, therefore, the current study applies certain methods of investigation such as research design, data gathering instruments method, the population of the study, the locale of the study, data gathering procedures, and the statistical treatment of data.

\section{Research Design of the study}

The research design of the study is the descriptive assessment and descriptive correlational research design. Ariola (2006) argued that a descriptive correlation study is intended to describe the relationship among variables without seeking to establish a causal connection. While descriptive research is simply to describe a population, a situation, or a phenomenon. It is also used to describe profiles, frequency distribution, describe characteristics of people, situations, or phenomena. In short, it answers the question of what, when, how, where, and not why question (McCombes, 2020).

\section{The locale of the Study}

The locale of the study was Divine Word Colleges namely, Divine Word College of Laoag and Divine Word College of Vigan. These two colleges are located in Vigan City, the heritage city of Ilocos Sur, and Laoag City, the capital of Ilocos Norte.

\section{Population}

The respondents of the study are the employees of these colleges. Since the number of employees is limited, therefore, the total enumeration sampling was used and thus all faculty and employees from the two colleges were taken as respondents of the study.

\section{Data Gathering instruments}

The study adopted validated questionnaires of Koopmans, et.al (2012) on work performance, Abun, et.al (2021) on the work environment, and Schwarzer and Jerusalem, (1995) on General Self-Efficacy (GSE). 


\section{Data Gathering Procedures}

To preserve the integrity of scientific research, the data were gathered after the approval of the Presidents of different colleges. The researcher sent a letter to the president and after the letters were approved, the questionnaires were distributed by the researcher's representative. Then the researcher's representative from each institution collected the data and submitted it to the researcher for tabulation.

\section{Ethical Procedures}

The study was carried out after the research ethics committee examined and approved the content of the paper if it does not violate ethical standards and if it does not cause harm to human life and the environment.

\section{Statistical Treatment of Data}

To analyze the data, a descriptive and inferential statistic was used. The weighted mean was used to determine the level of employees' self-efficacy, work of employees, and work environment and the Pearson $r$ was used to measure the correlation between employees' self-efficacy and work performance, work environment self-efficacy, and work performance. The following ranges of values with their descriptive interpretation will be used:

$\begin{array}{ll}\text { Statistical Range } & \text { Descriptive Interpretation } \\ 4.21-5.00 & \text { strongly agree/Very High } \\ 3.41-4.20 & \text { Agree/High } \\ 2.61-3.40 & \text { somewhat agree/ Moderate } \\ 1.81-2.60 & \text { Disagree/Low } \\ 1.00-1.80 & \text { Strongly disagree/Very Low }\end{array}$

Data Presentation and Analysis

As a scientific study, it must be supported by evidence that is gathered through data collection methodology. The study was guided by the statement of the problems and therefore, this part presents the data that was gathered through research questionnaires. The presentation follows the arrangement of the statement of the problems of the study.

What is the self-efficacy of the employees of Divine Word Colleges in the Ilocos Region?

Table 1: Self-efficacy of the employees of Divine Word Colleges in the Ilocos Region

\begin{tabular}{lcc}
\hline Self-efficacy & Mean & DR \\
\hline 1. "I will be able to achieve most of the goals that I have set for myself" & 4.09 & A \\
\hline 2. "When facing difficult tasks, I am certain that I will accomplish them" & 4.08 & A \\
\hline 3. "In general, I think that I can obtain outcomes that are important to me" & 4.14 & $\mathrm{~A}$ \\
\hline 4. "I believe I can succeed at most any endeavor to which I set my mind" & 4.14 & $\mathrm{~A}$ \\
\hline 5. "I will be able to successfully overcome many challenges" & 4.14 & $\mathrm{~A}$ \\
\hline 6. "I am confident that I can perform effectively on many different tasks" & 4.00 & $\mathrm{~A}$ \\
\hline 7. "Compared to other people, I can do most tasks very well" & 3.87 & $\mathrm{~A}$ \\
\hline 8. "Even when things are tough, I can perform quite well." & 4.14 & $\mathrm{~A}$ \\
\hline Composite Mean & 4.08 & $\mathrm{~A}$ \\
\hline
\end{tabular}

Source: Schwarzer, R., \& Jerusalem, M. (1995)

Based on the data presented in the table, it reveals that as a whole the employees' self-efficacy obtained a composite mean of 4.08 which is interpreted as "agree"/high. This composite mean indicates that employees' self-efficacy is not very high but high and it is also not very low, low, or moderate. This suggests that the employees highly believe that they can achieve their goals despite challenges or difficulties. Even when the items are taken singly, all are rated within the same level of mean rating with the same interpretation as "agree/high".

Such rating suggests that the employees agree that they can achieve most of the goals that they have set for themselves (4.09), can accomplish their difficult tasks (4.08), can obtain outcomes that are important to them (4.14), can succeed at most any endeavor to which they set their mind (4.14), can successfully overcome many challenges (4.14), can perform effectively on many different tasks (4.00), can do most tasks very well (3.87), and can perform quite well even when things are tough (4.14). 
What is the individual work performance of employees of Divine Word Colleges in the Ilocos Region in terms of Task performance, Contextual performance Counterproductive work behavior?

Table 2: Individual Work Performance of Employees of Divine Word Colleges in the Ilocos Region

\begin{tabular}{lcc}
\hline A. Task Performance (TP) & Mean & DR \\
\hline 1. I manage to plan my work so that it was done on time. & 4.15 & $\mathrm{~A}$ \\
\hline 2. My planning was optimal. & 4.01 & $\mathrm{~A}$ \\
\hline 3. I kept in mind the results that I have to achieve in my work. & 4.08 & $\mathrm{~A}$ \\
\hline 4. I was able to separate main issues from side issues at work. & 4.05 & $\mathrm{~A}$ \\
\hline 5. I knew how to set the right priorities. & 4.10 & $\mathrm{~A}$ \\
\hline 6. I was able to perform my work well with minimal time and effort. & 3.99 & $\mathrm{~A}$ \\
\hline Composite Mean & 4.06 & $\mathrm{~A}$ \\
\hline
\end{tabular}

Source: Koopmans, et.al (2012).

As gleaned from the data on the table, it shows that as a whole, the individual work performance of employees in terms of task performance gains a composite mean of 4.06 which means "agree/high". This composite mean demonstrates that the task performance of employees is not considered very high and it is also not considered very low, low, or moderate but it is high. Such rating points out that the employees highly perform their tasks. Even if the items are taken separately, they all fall within the same level of mean rating with the same interpretation as agree/high". It means that the employee agrees that they manage to plan their work so that it was done on time (4.15), and their planning was optimal (4.01). Further, they all agree that they kept in mind the results that they have to achieve in their work (4.08), separate main issues from side issues at work (4.05), knew how to set the right priorities (4.10), and can perform their work well with minimal time and effort (3.99).

Table 3: Contextual Performance

\begin{tabular}{lcc}
\hline Contextual Performance (CP) & 4.08 & $\mathrm{~A}$ \\
\hline 1. I took on extra responsibilities. & 4.00 & $\mathrm{~A}$ \\
\hline 2. I started a new task myself when my old ones were finished. & 3.97 & $\mathrm{~A}$ \\
\hline 3. I took on a challenging work task, when available. & 4.00 & $\mathrm{~A}$ \\
\hline 4. I worked at keeping my job knowledge up-to-date. & 4.11 & $\mathrm{~A}$ \\
\hline 5. I worked at keeping my job skills up-to-date. & 3.97 & $\mathrm{~A}$ \\
\hline 6. I came up with creative solutions to new problems. & 3.93 \\
\hline 7. I kept looking for new challenges in my job. & 3.96 \\
\hline 8. I did more than was expected of me. & 4.00 \\
\hline 9. I actively participated in work meetings. & $\mathrm{A}$ \\
\hline 10. I actively look for ways to improve my performance at work. & $\mathrm{A}$ \\
\hline 11. I grasped opportunities when they presented themselves. & 4.07 \\
\hline 12. I knew how to solve difficult situations and setbacks quickly. & $\mathrm{A}$ \\
\hline Composite Mean & 4.07 \\
\hline
\end{tabular}

Source: Koopmans, et.al (2012)

As indicated by the data on the table, it manifests that as a whole, the individual performance of employees receives a composite mean rating of 4.01 which is described as "agree/high".

This composite mean rating signifies that the individual performance of employees in terms of contextual performance is not very high and it is also not very low, low, or moderate but it is high. It suggests that employees highly perform extra behaviors or extra tasks that help their work and the organization. In other words, their organizational citizenship behavior is considered high. Even when the items are taken singly, all are rated within the same level of mean rating with the same description as "agree/high".

This rating conveys an agreement that all employees agree that they took on extra responsibilities (4.08), started a new task themselves when their old ones were finished (4.00), took on a challenging work task, when available (3.97), worked at keeping their job knowledge up-to-date (4.00), worked at keeping my job skills up-to-date (4.11), came up with creative solutions to new problems (3.97), kept looking for new challenges in their job (3.93), did more than was expected of them (3.96), actively participated in work meetings (4.00), actively look for ways to improve their performance at work (4.07), grasped opportunities when they presented themselves (4.07), and knew how to solve difficult situations and setbacks quickly (4.00). 
Table 4: Counterproductive behavior

\begin{tabular}{lll}
\hline C. Counterproductive work behavior (CWB) & \\
\hline 1. I complained about unimportant matters at work. & 2.53 & DA \\
\hline 2. I made problems greater than they were at work. & 2.46 & DA \\
\hline 3. I focused on the negative aspects of a work situation, instead of on the positive aspects. & 2.18 & DA \\
\hline 4. I spoke with colleagues about the negative aspects of my work. & 2.41 & DA \\
\hline 5. I spoke with people from outside the organization about the negative aspects of my work. & 2.26 & DA \\
\hline 6. I did less than was expected of me. & 2.40 & DA \\
\hline 7. I managed to get off from a work task easily. & 2.31 & DA \\
\hline 8. I sometimes did nothing, while I should have been working. & 2.27 & DA \\
\hline Composite Mean & 2.35 & DA \\
\hline
\end{tabular}

Source: Koopmans, et.al (2012).

As we see the data on the table, it reveals that as a whole, individual performance of employees in terms of counterproductive behavior obtains a composite mean rating of 2.35 which is described as "disagree/low". This rating recommends that as a whole, the employees' performance in terms of counterproductive behavior is not very high or high and it is also not moderate or very low but it is low. This suggests that as a whole the employees' counterproductive behavior is low. Even if all items are taken separately, they are all rated within the same level of mean rating with the same description as "disagree/low" It means that the employees disagree they complained about unimportant matters at work (2.53), made problems greater than they were at work (2.46), focused on the negative aspects of a work situation, instead of on the positive aspects (2.18), spoke with colleagues about the negative aspects of their work (2.41), spoke with people from outside the organization about the negative aspects of their work (2.26), did less than was expected of them (2.40), managed to get off from a work task easily (2.31), and sometimes did nothing, while they should have been working (2.27).

Table 5: Summary Table

\begin{tabular}{lcc}
\hline Work Performance & & \\
\hline Task Performance & 4.06 & $\mathrm{~A}$ \\
\hline Contextual performance & 4.01 & $\mathrm{~A}$ \\
\hline Counterproductive behavior & 2.35 & $\mathrm{DA}$
\end{tabular}

As we see in the summary table, it depicts an explanation that task performance of employees of the Divine Word Colleges in the Ilocos Region particularly task and contextual performance is not very high and it is also not very low, low, or moderate but it is high. This suggests that the employees have a high degree of skills and competence to perform their task and have a high degree of productive behavior or the extra behaviors that are needed to perform their task. This is evidenced by the lower degree of their counterproductive behavior. Their counterproductive behavior rating is low which indicates that their behaviors are not too harmful for the organization.

What is the work environment of the Divine Word Colleges in the Ilocos Region in terms of Bureaucratic environment, Humanistic environment and Working relationship?

Table 6: Work Environment of the Divine Word Colleges in the Ilocos Region

\begin{tabular}{llc}
\hline A. Bureaucratic Work Environment & Mean & DR \\
\hline 1. Employees are always doing the same job and the same way every day. & 3.39 & $\mathrm{~A}$ \\
\hline 2. All employees must follow the established rules and procedures. & 3.76 & $\mathrm{~A}$ \\
\hline 3. There is little action taken until a supervisor or the higher up approves a decision. & 3.69 & $\mathrm{~A}$ \\
\hline 4. Even small matters have to be referred to someone higher up for a final answer. & 3.53 & $\mathrm{~A}$ \\
\hline 5. In general, a person who wants to make his/her own decisions would be quickly discouraged. & 3.30 & $\mathrm{SWA}$ \\
\hline 6. Employees are working under close monitoring of their supervisor. & 3.59 & $\mathrm{~A}$ \\
\hline 7. One cannot do his/her job in his/her way but he/she has to follow the rules and procedures. & 3.60 & $\mathrm{~A}$ \\
\hline 8. Communications, decisions, and proceedings are put in writing for future references. & 3.82 & $\mathrm{~A}$ \\
\hline 9. Employees are afraid of violating the rules because it means punishment. & 3.71 & $\mathrm{~A}$ \\
\hline 10. Employees are expected to respect the chain of command. & 3.81 & $\mathrm{~A}$ \\
\hline Composite Mean & 3.62 & $\mathrm{~A}$ \\
\hline Source: Abun, et (2021) &
\end{tabular}

Source: Abun, et.al (2021). 
Looking at the data on the table, it appears that as a whole, the work environment of the Divine Word Colleges in the Ilocos Region in terms of bureaucratic environment obtained a composite mean rating of 3.62 which is understood as "agree/high". This composite mean rating points out that the work environment of the Divine Word Colleges in terms of bureaucratic environment is not considered very high and it is not also very low, low, or moderate but it is high. This suggests that the environment is highly bureaucratic in which everything relies highly on rules and procedures. Reading the items separately, it shows that majority of the items are rated within the same level of mean rating ranges with the description of "agree/high" It suggests that all employees agree that they must follow the established rules and procedures (3.76), there is no action taken until a supervisor or the higher up approves a decision (3.69), small matters have to be referred to someone higher up for final answer (3.53), are working under close monitoring of their supervisor (3.59), cannot do their job in their way but they have to follow the rules and procedures (3.60), communications, decisions, and proceedings are put in writing for future references (3.82), are afraid of violating the rules because it means punishment (3.71), are expected to respect the chain of command" (3.81) and are always doing the same job and the same way every day (3.39). There was only one item rated with the mean rating of 3.30 with the interpretation of "somewhat agree/moderate" that in general, a person who wants to make his/her own decisions would be quickly discouraged.

Table 7: Humanistic Management Style

\begin{tabular}{lcc}
\hline B. Humanistic environment & 3.36 & SWA \\
\hline 1. The management considers the ideas of employees when making decisions. & 3.36 & SWA \\
\hline 2. The management always tries their best to serve the needs of employees. & 3.34 & SWA \\
\hline 3. The management listens to the employees when the employees counter problems in their work. & 3.38 & SWA \\
\hline 4. The management respect and treat the employees as human beings with dignity. & 3.31 & SWA \\
\hline 5. The management recognizes the good effort of the employees to help the institution. & 3.33 & SWA \\
\hline 6. There is open communication between employees and management. & 3.31 & SWA \\
\hline $\begin{array}{l}\text { 7. When making decisions, the management always considers the effect of the decision on the } \\
\text { employees. }\end{array}$ & 3.27 & SWA \\
\hline 8. The management prioritizes the employees' condition first before the work. & 3.33 & SWA \\
\hline Composite Mean &
\end{tabular}

Source: Abun, et.al (2021).

Looking into the work environment in terms of humanistic work environment, the data shows that as a whole the humanistic environment of the Divine Word Colleges garnered a composite mean rating of 3.33 which means "somewhat agree/moderate". This composite mean rating indicates that as a whole, the work environment of Divine Word Colleges in terms of humanistic work environment is not very high or high and it is also not very low or low but it is at a moderate extent. This suggests that as a whole, the humanistic work environment of the Divine Word Colleges is the only moderate extent which means that the environment is not highly humanistic but it is moderately humanistic particularly in terms of management approach dealing with the employees such as considering the ideas of employees (3.36), serving the needs of employees (3.36), listening to the employees when they have problems (3.34), respecting and treating the employees with dignity (3.38), recognizing the contribution of employees (3.31), opening communication line with the employees (3.33), considering the effect of their decisions to the employees (3.31), and prioritizing the employees' condition first before the work (3.27).

Table 8: Work Relationship

\begin{tabular}{|c|c|c|}
\hline C. Work Relationship & & \\
\hline 1. There is a trust relationship between supervisors and subordinates. & 3.45 & A \\
\hline There is a trust relationship among employees. & 3.53 & A \\
\hline $\begin{array}{l}\text { 3. Employees can easily get the cooperation of other employees in community programs or } \\
\text { activities. }\end{array}$ & 3.46 & A \\
\hline 4. $\quad$ Supervisors support their subordinates and subordinates support their supervisors. & 3.47 & A \\
\hline $\begin{array}{l}\text { 5. Supervisors feel free to give feedback to their subordinates and subordinates feel free to give } \\
\text { feedback to their supervisors. }\end{array}$ & 3.50 & A \\
\hline 6. Employees support one another whenever there is a need for support. & 3.57 & A \\
\hline 7. Employees often give feedback to their fellow employees even it is negative feedback. & 3.36 & SWA \\
\hline $\begin{array}{l}\text { 8. Supervisors provide regular feedback to their subordinates and subordinates are happy to } \\
\text { receive the feedback from their supervisors. }\end{array}$ & 3.48 & A \\
\hline $\begin{array}{l}\text { 9. Supervisors allow subordinates to participate in decision - making and subordinates can make } \\
\text { their own decisions. }\end{array}$ & 3.55 & A \\
\hline 10. Employees can communicate openly with other employees without hesitation. & 3.51 & A \\
\hline Composite Mean & 3.49 & A \\
\hline
\end{tabular}

Source: Abun, et.al (2021) 
Concerning the work environment in terms of a working relationship, the data displays that as a whole, the work environment in terms of work relationship gains a composite mean rating of 4.49 which is interpreted as "agree/high". This mean rating indicates that as a whole work environment in terms of work relationships is not very high and it is also not very low, low, or moderate but it is high. As whole employees highly agree that there is a trust between employees and employers (3.45), there is a trust among employees (3.53), can easily get the cooperation of other employees in community programs or activities (3.46), supervisors support their subordinates and subordinates support their supervisors (3.47), supervisors feel free to give feedback to their subordinates and subordinates feel free to give feedback to their supervisors (3.50), employees support one another whenever there is a need for support (3.57), supervisors provide regular feedback to their subordinates and subordinates are happy to receive the feedback from their supervisors (3.48), Supervisors allow subordinates to participate in decision - making and subordinates can make their own decisions (3.55), employees can communicate openly to other employees without hesitation (3.51), but somewhat agree that employees often give feedback to their fellow employees even it is negative feedbacks (3.36).

\section{Summary Table}

Table 9: Summary of Work Environment

\begin{tabular}{lll}
\hline ITEMS & Mean & DR \\
\hline 1. Bureaucratic Work Environment & 3.62 & $\mathrm{~A}$ \\
\hline 2. Humanistic environment & 3.33 & SWA \\
\hline 3. Working Relationship environment & 3.49 & $\mathrm{~A}$ \\
\hline Overall Mean & $\mathbf{3 . 4 9}$ & $\mathbf{A}$ \\
\hline
\end{tabular}

Based on the summary table, it shows that as a whole, the work environment of the Divine Word Colleges in the Ilocos Region is rated at 3.49 which is interpreted as "agree/high". It means that the employees confirm the practice of bureaucratic leadership style, humanistic management style, and working relationship. Looking at individual dimensions, the bureaucratic work environment is rated higher than humanistic and work relationships. The lowest is the humanistic environment which suggests that the higher the bureaucratic leadership practices are, the lower the humanistic and working relationship environment are.

\section{Is there a relationship between self-efficacy and individual work performance?}

Table 10: Relationship between Self-efficacy and Individual Work Performance

\begin{tabular}{lllll}
\hline & Task Performance & $\begin{array}{l}\text { Contextual } \\
\text { Performance }\end{array}$ & $\begin{array}{l}\text { Counter } \\
\text { Productive } \\
\text { behavior }\end{array}$ \\
\hline Self-Efficacy & & & .016 \\
\cline { 2 - 5 } & Pearson Correlation & $.800^{* *}$ & $.797^{* *}$ & .814 \\
\cline { 2 - 5 } & Sig. (2-tailed) & .000 & .000 & 207 \\
\hline
\end{tabular}

**. Correlation is significant at the 0.01 level (2-tailed).

Answering the statement of problem number 4, the Pearson $r$ correlation coefficient table demonstrates that there is a significant correlation at 0.01 level (2-tailed) between self-efficacy and work performance particularly task performance and contextual performance but there is no correlation between self-efficacy and counterproductive behavior. In other words, self-efficacy affects positive behavior and negative behavior.

Is there a relationship between work environment and self-efficacy?

Table 11: Relationship between Work Environment and Self-Efficacy

\begin{tabular}{|c|c|c|}
\hline & & SELF EFFICACY \\
\hline \multirow[t]{3}{*}{ Bureaucratic Environment } & Pearson Correlation & .131 \\
\hline & Sig. (2-tailed) & .060 \\
\hline & $\mathrm{N}$ & 207 \\
\hline \multirow[t]{3}{*}{ Humanistic Environment } & Pearson Correlation & $.245^{* *}$ \\
\hline & Sig. (2-tailed) & .000 \\
\hline & $\mathrm{N}$ & 207 \\
\hline \multirow[t]{3}{*}{ Working Relationship } & Pearson Correlation & $.260^{* *}$ \\
\hline & Sig. (2-tailed) & .000 \\
\hline & $\mathrm{N}$ & 207 \\
\hline
\end{tabular}

**. Correlation is significant at the 0.01 level (2-tailed). 
Based on the Pearson r correlation table, demonstrates that not all dimensions of the work environment affect self-efficacy. The data reveals that a bureaucratic work environment does not affect self-efficacy but humanistic and working relationships do affect the self-efficacy of employees. This suggests that developing the employees' self-efficacy requires humanistic and working relationships. In other words, creating a humanistic environment and conducive working relationship is necessary to develop the self-efficacy of the employees. Even if the employees have the self-efficacy to perform their tasks but if the work environment is not supportive, like bureaucracy, then the self-efficacy cannot be developed and cannot be translated into performance.

\section{Is there a relationship between work environment and individual work performance?}

Table 12: Relationship between Work environment and Individual Work Performance

\begin{tabular}{lllll}
\hline & & Task Performance & $\begin{array}{l}\text { Contextual } \\
\text { Performance }\end{array}$ & Counter-Productive \\
\hline Bureaucratic Environment & Pearson Correlation & $.213^{* *}$ & $.215^{* *}$ & $.222^{* *}$ \\
\cline { 2 - 5 } & Sig. (2-tailed) & .002 & .002 & .001 \\
\cline { 2 - 5 } & $\mathrm{N}$ & 207 & 207 & 207 \\
\hline \multirow{2}{*}{$\begin{array}{l}\text { Humanistic } \\
\text { Environment }\end{array}$} & Pearson Correlation & $.284^{* *}$ & $.318^{* *}$ & $.189^{* *}$ \\
\cline { 2 - 5 } & Sig. (2-tailed) & .000 & .000 & .006 \\
\cline { 2 - 5 } $\begin{array}{l}\text { Work } \\
\text { Relationship }\end{array}$ & $\mathrm{N}$ & 207 & 207 & 207 \\
\cline { 2 - 5 } & Pearson Correlation & $.303^{* *}$ & $.310^{* *}$ & .009 \\
\cline { 2 - 5 } & Sig. (2-tailed) & .000 & .000 & 207 \\
\hline
\end{tabular}

**. Correlation is significant at the 0.01 level (2-tailed).

Related to the statement of problem number 6 about the relationship between work environment and individual work performance, the Pearson $\mathrm{r}$ correlation coefficient table reveals that there is a significant relationship between work environment and individual work

performance. All three dimensions of work environment measured by this study pointed out that bureaucratic, humanistic, and work relationships are all correlated to task performance, contextual performance, and counterproductive behavior. This finding suggests that improving work performance requires a positive work environment.

\section{Result and Discussion}

Based on the finding of the study, it shows that the self-efficacy of the employees is considered high and it follows that their task and contextual performance is also high but not with the counterproductive behavior and it is confirmed by the Pearson $r$ correlation coefficient that high self-efficacy affects high task and contextual performance but not with the counterproductive behavior. It means that self-efficacy affects only the positive behavior and not the negative behavior. It has nothing to do with the harmful behavior of the employees. This finding suggests that improving task performance and contextual performance requires the development of selfefficacy and when the employees have higher self-efficacy and higher skills or competencies and have high contextual performance (extra productive behaviors) that help them perform their task, then consequently lead to lowering their counterproductive behavior.

However, the finding also pointed out that self-efficacy can only be realized when the work environment is supportive of the exercise of self-efficacy. This is supported by the finding of the study, that the two dimensions of the three work environments such as humanistic environment and work relationship that are identified by this study are all correlated to self-efficacy, while the bureaucratic environment is not correlated to self-efficacy. This finding demonstrates that the more humanistic the work environment is and the better the working relationship among employees and the supervisors is, the higher the self-efficacy becomes. Thus, this study argues that self-efficacy can affect work performance as long as the work environment is humanistic and the working relationship is harmonious and not bureaucratic. Bureaucratic does not help promote self-efficacy. Therefore, the mediating factor between self-efficacy and work performance is the work environment and this study points out that the three dimensions of work environment affect work performance. The result of this study explains that self-efficacy is not a single predictor of work performance.

The study contributes to enrich the discussion of the effect of self-efficacy on work performance. It only affects the positive or productive work behavior and not the negative work behavior or counterproductive work behavior. However, it is not only a single predictor to work performance, it has to be supported by the humanistic work environment and conducive work relationships. The bureaucratic environment needs to be minimized.

\section{Conclusion}

The study aimed to determine the effect of self-efficacy on individual performance as mediated by the work environment. Based on the six statements of the problems proposed by this study, it concludes that the self-efficacy of the employees of the Divine Word 
Colleges is considered high and the self-efficacy correlates to the two dimensions of work performance such as task and contextual performance but not the counterproductive behavior. Self-efficacy affects only the positive behavior and not the negative behaviors. The study further concludes that self-efficacy cannot affect performance alone without a supportive work environment. The work environment can affect self-efficacy and work performance. Solving work performance requires the development of self-efficacy and improving the work environment. Based on the findings, therefore, the hypotheses of the study are accepted.

\section{References}

Abun, D., Magallanes, T., Basilio, G.J.Q., Encarnacion, M.J. \& Sallong, M. (2021). Examining the link between organizational citizenship behavior and work performance of employees in the private schools, mediated by the workplace environment. International Journal of Research in Business and Social Science, 10(4), 85-98.

Abun, D., Ranay, F.B., Magallanes, T., Encarnacion, M.J., \& Alkalde, F. (2020). Employee Treatment and Work Engagement: The Philippine Context. Proteus Journal, 11 (10).

Abun, D., Macaspac, L.G.R., Magallanes, T. \& Encarnacion, M.J. (2020). Corporate Transparency Practices in the School Management and Work Engagement of Employees in the Ilocos Region, Philippines. Proteus Journal, 11(10).

Abun, D. Magallanes, T., Acidera, E.B., Encarnacion, M.J. Domingcil, C.U. (2021). Work Environment and work Engagement of Employees of the Catholic Colleges in the Ilocos Region, Philippines. Technium Social Science Journal, 19, 439-464.

Abun, D., Magallanes, T., Paynaen, H., Foronda, S.L.G.L., \& Pre, M. (2019). The Effect of Workplace Relationship toward Job Satisfaction of Divine Word Colleges' Employees in Region I, Philippines. International Journal of Modern Research in Engineering \& Management (IJMREM), 1 (11), 53-63.

Al-Omari, K. \& Okasheh, H. (2017). The Influence of Work Environment on Job Performance: A Case Study of Engineering Company in Jordan. International Journal of Applied Engineering Research, 12(24), 15544-15550.

Arinanye, R. T. (2015). Organizational factors affecting employee performance at the College of Computing and Information Sciences (COCIS). Makerere University, Kampala, Uganda (Unpublished master dissertation). Uganda Technology And Management University, Kampala, Uganda

Ariola, M.M. (2006). Principles and Methods of Research. Manila: Rex Book Store

Austin, J.T. and Villanova, P. (1992). The criterion problem: 1917-1992. Journal of Applied Psychology, 77(6), 836-74.

Awan, A.G. \& Tahir, M.T. (2015). Impact of working environment on employee's productivity: A case study of Banks and Insurance Companies in Pakistan. European Journal of Business and Management, 7(1).

Bandura, A (1977). Self-efficacy: Toward a Unifying Theory of Behavioral Change. Psychological Review. 84 (2): $191-215$.

Bandura, A. (1997b). Self-Efficacy: The Exercise of Control. New York: Freeman.

Bandura, A. (1989). Human Agency in Social Cognitive Theory. American Psychologist, 44, 1175-1184.

Bandura, A. (1995). Self-Efficacy in Changing Societies. New York: Cambridge University.

Borman, W.C. \& Motowidlo, S.J. (1993). Task Performance and Contextual Performance: The Meaning for Personnel Selection Research. Human Performance, 10(2).

Briner, R.B. (2000). Relationship between Work Environment, Psychological Work Environment, and Psychological Well-Being: indepth Review. Occup. Med. 50 (5). Retrieved from http://occmed.oxfordjournals.org.

Campbell, J. (1990). Modeling the performance prediction problem in industrial and organizational psychology. In M. Dunnette \& L. Hough (Eds.), Handbook of industrial and organizational psychology (pp. 686-707). Palo Alto, CA: Consulting Psychologists Press.

Cetin, F., \& Askun, D. (2019). The effect of occupational self-efficacy on work performance through intrinsic work motivation. Management Research Review, 41(2), 186-201. https://doi.org/10.1108/MRR-03-2017-0062

Cherian, J. \& Jacob, J. (2013). Impact of Self Efficacy on Motivation and Performance of Employees. International Journal of Business and Management, 8(14). htts://doi.org/10.5539/ijbm.v8n14p80.

Ching, F.C., Singh, J. \& Arumugam, T. (2020). Employee Contextual Performance, Social Intelligence, Spiritual Intelligence: A quantitative study in Malaysia. International Journal of Psychosocial Rehabilitation 24(02):968-981. https://doi.org/10.37200/IJPR/V24I2/PR200404

Conger, J. A. \& Kanungo, R.N. (1988). Empowerment Process: Integrating Theory and Practice. The Academy of Management Review, 13 (3), 471-482.

Duru, C.E. \& Shimawua, D. (2017). The Effect of Work Environment on Employee Productivity: A Case Study of Edo City Transport Services Benin City, Edo State Nigeria. European Journal of Business and Innovation Research, 5(5), 23-29.

Fox, S., Spector, P. E., Miles, D. (2001). Counterproductive Work Behavior (CWB) in Response to Job Stressors and Organizational Justice: Some Mediator and Moderator Tests for Autonomy and Emotions. Journal of Vocational Behavior, 59, 291-309 https://doi.org/10.1006/jvbe.2001.1803, available online at http://www.idealibrary.com

Griffin, M.A, Neal A., \& Parker, S. K. (1993). A new model of work role performance: Positive behavior in uncertain and interdependent contexts. Acad Manag J. 50, 327-347.

Heathfield, S.M. (2021). Examples of Adding Value in Your Organization. Careers. Retrieved from https://www.thebalancecareers.com/value-add-in-a-company-1918286

Kalia, N. \& Bhardwaj, B. (2019). Contextual and Task Performance: Do Demographic and Organizational variables matter? Rajagiri Management Journal, 13(2), 30-42. 
Koopmans, L., Bernaards, C., Hildebrandt, V., van Buuren, S., van der Beek, A.J. \& de Vet, H.C.W. (2012). Development of an individual work performance questionnaire. International Journal of Productivity and Performance Management, 62(1), 6 28. https://doi.org/10.1108/17410401311285273

Koopmans, L., (2011). Measuring Individual Work Performance. Journal of Occupational and Environmental Medicine, 56(3).

Koshal (2014). Difference between Concept and Theory. Retrieved from https://www.differencebetween.com/difference-betweenconcept-and-vs-theory/

Leedy, P.D. (1974). Practical research: planning and design. New York: Macmillan

Lopes-Garrido, G. (2020). Self-Efficacy Theory. Simply Psychology. Retrieved from https://www.simplypsychology.org/selfefficacy.html

Machmud, S. (2018). The Influence of Self-Efficacy on Satisfaction and Work-Related Performance. International Journal of Management Science and Business Administration, 4(4), 43-47.

Macovei, C.M. (2016). Counterproductive Behaviors and Work Performance in Military Organization. International Conference Knowledge-Based Organization, 22(2).

Mansoor, F. \& Hassan, Z. (2016). Factors influencing Employee Engagement: A study on a Telecommunication Network provider in the Maldives. International Journal of Accounting \& Business Management, 4 (1). https://doi.org/10.24924/ijabm/2016.04/v4.iss1/50.64

Marchington, M. \& Wilkinson, A. (2005). Direct participation and involvement', in S. Bach Managing Human Resources: Personnel Management in Transition, 4th edition. Oxford: Blackwell, 398-423.

Martocchio (2015). Pay, Compensation, and Performance Psychology. In International Encyclopedia of the Social \& Behavioral Sciences (Second Edition). Amsterdam: Elsevier.

McCombes, S. (2020). Descriptive Research. Scribbr. Retrieved from https://www.scribbr.com/methodology/descriptive-research/

Motowidlo, S.J. \& Kell, H.J. (2012). Job Performance. In book: Handbook of psychology, vol. 12: Industrial and organizational psychology, $2^{\text {nd }}$ Edition. New York: Wiley.

Motowidlo, S.J. \& Van-Scotter, J.R. (1994). Evidence that task performance should be distinguished from contextual performance. Journal of Applied Psychology, 79(4), 475-480.

Motowidlo, S. J. (2003). Job performance. In W. C. Borman, D. R. Ilgen, \& R. J. Klimoski (Eds.). Handbook of psychology: Industrial and organizational psychology, 12, 39-53. New York: John Wiley \& Sons Inc.

Mount, M., Ilies, R., Johnson, E. (2006). Relationship of Personality Traits and Counterproductive Work Behaviors: The mediating Effects of Job Satisfaction. Personnel Psychology, 59, 591-622.

MSG: Management Study Guide (n.d). What is Employee Relation? Retrieved from https://www.managementstudyguide.com/whatis-employee-relations.htm

Nassazi, N. (2013). Effects of training on employee performance: Evidence from Uganda (Unpublished doctoral dissertation). University of Applied Sciences, Vassa, Finland.

Nitisemito, A. S. (1992). Personnel management, Ninth mold (4th Ed.). Jakarta: Ghalia Indonesia.

Nordlof, C., Hallstrom, J. \& Host, G.E. (2019). Self-efficacy or context-dependency? Exploring teachers' perceptions of and attitudes towards technology education. International Journal of Technology and Design Education, 29, 123-141.

Oludeyi, O.S. (2015). A Review of Literature on Work Environment and Work Commitment: Implication for Future Research in Citadels of Learning. Journal of Human Resource Management, 2(5).

Opperman, C. S. (2002). Tropical Business Issues. Partner Price Water House Coopers. Retrieved from www.pricewaterhousecoopers//zambiaeconomists .com

Organ, D.W. (2015). Organizational Citizenship Behavior. In International Encyclopedia of the Social \& Behavioral Sciences (Second Edition). Amsterdam: Elsevier.

Othman, R. B., Rapi, R. B. M., Alias, N. E. B., Jahya, A. B., \& Loon, K. W. (2019). Factors Affecting Employee Engagement: A Study among Employees in the Malaysian Construction Industry. International Journal of Academic Research in Business and Social Sciences, 9(7), 784-797

Pandey, P. (2017). The impact of work environment on employees' productivity. Munich: GRIN Verlag. Retrieved from https://www.grin.com/document/412794

Parimita, W., Purwana, D., Fadillah, N., Zahra, F.S. \& Suparno. (2020). The Effect of Self-Efficacy and Communication Skills on Employee Performance and Work Engagement at Online Transportation Companies. International Journal of Innovation, Creativity, and Change, 13(1).

Podsakoff, P.M., MacKenzie, S.B., Paine, J.B. and Bachrach, D.G. (2000). Organizational citizenship behaviors: a critical review of the theoretical and empirical literature and suggestions for future research. Journal of Management, 26 (3), 513-563.

Randhawa, G. (2004). Self-Efficacy and Work Performance: An Empirical Study. Indian Journal of Industrial Relations, 39(3), 336346.

Raudenbush, S.W., Rowan, B. \& Cheong, Y.F. (1992). Contextual Effects on the Self-Perceived Efficacy of High School Teachers. Sociology of Education, 65(2), 150-167.

Redmond, B. F. (2010). Self-Efficacy Theory: Do I think that I can succeed in my work? Work Attitudes and Motivation. Pennsylvania: State University, World Campus.

Robbins, S.P. \& Judge, T.A. (2013). Organizational Behavior. Boston: Pearson. 
Rotundo, M. and Sackett, P.R. (2002). The relative importance of task, citizenship, and counterproductive performance to global ratings of performance: a policy-capturing approach. Journal of Applied Psychology, 87(1), 66-80.

Sackett, P.R., and Devore, C.J. (2001). Counterproductive Behaviors at Work. In: Anderson, N., Ones, D., Sinangil, H. and Viswesvaran, C., Eds., Handbook of Industrial, Work, and Organizational Psychology. London: Sage, 145-164

Sackett, P. R., DeVore, C. J. (2002). Counterproductive behaviors at work. In N. Anderson, D. S. Ones, H. K. Sinangil, \& V. Viswesvaran (Eds.), Handbook of Industrial, Work, and Organizational Psychology, 1, 145-164. London: Sage.

Saks, A.M. (1995). Longitudinal Field Investigation of the Moderating and Mediating Effects of Self-Efficacy on the Relationship between Training and New Comer Adjustment. Journal of Applied Psychology, 80, 211-225.

Schreiner, E. (2018). What is an Employer-Employee Relationship? Chron. Retrieved from https://smallbusiness.chron.com/employeremployee-relationship-16737.html

Schwarzer, R., \& Jerusalem, M. (1995). Generalized Self-Efficacy scale. In J. Weinman, S. Wright, \& M. Johnston, Measures in health psychology: A user's portfolio. Causal and control beliefs (35- 37). Windsor, England: NFER-NELSON

Short, J. C., \& Palmer, T. B. (2003). Organizational performance referents: An empirical examination of their content and influences. Organizational Behaviour and Human Decision Processes, 90, 209-224.

Sonnentag, S., \& Frese, M. (2002). Performance concepts and performance theory. Psychological management of individual performance, 23(1), 3-25.

Sypniewska B. (2020). Counterproductive Work Behavior and Organizational Citizenship Behavior. Adv Cogn Psychol, 10; 16(4):321-328. https://doi.org/10.5709/acp-0306-9. PMID: 33500742; PMCID: PMC7809919

Tojjari, F., Esmaeilli, M.R., Bawandpour, R. (2013). The effect of self-efficacy on job satisfaction of sports referees. European Journal of Experimental Biology, 3(2):219-225

Walden, R. (2004). Work Environments. In Encyclopedia of Applied Psychology. Amsterdam: Elsevier

Wilkinson, D. (2000). The researcher's toolkit: the complete guide to practitioner research. New York: Routledge/Falmer

Wood, R. \& Bandura, A. (1989). Impact of Conceptions of Ability on Self-Regulatory Mechanism and Complex Decision-Making. Journal of Personality and Social Psychology, 56, 407-415.

Zulkosky, K. (2009). Self-Efficacy: A Concept Analysis. Nursing Forum, 44(2), 93-102

Publisher's Note: SSBFNET stays neutral with regard to jurisdictional claims in published maps and institutional affiliations.

\section{(c) (i)}

(C) 2021 by the authors. Licensee SSBFNET, Istanbul, Turkey. This article is an open access article distributed under the terms and conditions of the Creative Commons Attribution (CC BY) license (http://creativecommons.org/licenses/by/4.0/).

International Journal of Research in Business and Social Science (2147-4478) by SSBFNET is licensed under a Creative Commons Attribution 4.0 International License. 